\title{
PUBLIC ORGANIZATIONS AND PROCESS APPROACH
}

\author{
Anna Maria HORODECKA ${ }^{1 *}$, Monika ODLANICKA-POCZOBUTT ${ }^{2}$ \\ ${ }^{1}$ Silesian University of Technology, Faculty of Organization and Management, Institute of Management, \\ Administration and Logistics; anna.horodecka@polsl.pl, ORCID: 0000-0001-9853-3806 \\ ${ }^{2}$ Silesian University of Technology, Faculty of Organization and Management, Institute of Management, \\ Administration and Logistics; monika.odlanicka-poczobutt@polsl.pl, ORCID: 0000-0001-7834-1188 \\ * Correspondence author
}

Purpose: The objective of this article was therefore to review the concepts concerning the essence of process approach with regard to public organizations. The scope of the overview included initial analysis of the possibilities to use this approach in common courts.

Design/methodology/approach: In the literature of the subject, the concept of process approach more and more often is presented in the context of public organizations. This is often caused by the necessity to implement pro-effectiveness activities, the lack of funds that the public organizations have at their disposal, as well as by the increasing number of public tasks. Therefore, there is a search for solutions that would allow for the increase of effectiveness and for the improvement of efficiency of functioning of public organization, just as it is the case of business organizations.

Findings: The activity of public organizations is usually characterized by a sequence of complex activities that are subject to achieving goals being important for the proper functioning of the society. The dynamically developing economic practice forces changes towards focus on activities that create value for the citizen.

Research limitations/implications: Currently, it is believed that the essence of management of public organizations results from the nature of goals implemented by these organizations as well as from the complex surroundings. However, the objectives implemented by these organizations are different than the commercial ones.

Practical implications: The processes implemented in organizations should be perceived as separate wholes with organic features that can be observed, separated and shaped no matter the industry in which they function. The correctly identified processes would allow for standardization of activities of public organizations.

Originality/value One of the most important orientations, when it comes to managing modern organizations, is the process approach; however, its use in terms of public organizations requires taking into account their specific nature.

Keywords: public organizations, process approach, process approach in courts

Category of the paper: Theorethical paper. 


\section{Introduction}

In the literature of the subject, the concept of process approach more and more often is presented in the context of public organizations. This is often caused by the necessity to implement pro-effectiveness activities, the lack of funds that the public organizations have at their disposal, as well as by the increasing number of public tasks. Therefore, there is a search for solutions that would allow for the increase of effectiveness and for the improvement of efficiency of functioning of public organization, just as it is the case of business organizations. From among the basic methods for improving the functioning of public organizations, in the recent years, the implementation of process approach in such organizations is being indicated (Wiatrak, 2006, p. 221-224).

In the literature of the subject it is indicated that it is possible to distinguish certain features that are characteristic for processes taking place in the public organizations. Among them there are such features as (Kauf, 2015):

- homogeneity of the initiator at the process start, as in public organizations the initiator is usually the employer,

- sequentiality of activities that when implemented transform the input elements into output elements,

- measurability of objectivities achieved by way of creating and achieving the expected value,

- repetitiveness being the basis for developing implementation models of public benefits.

Currently, it is believed that the essence of management of public organizations results from the nature of goals implemented by these organizations as well as from the complex surroundings. However, the objectives implemented by these organizations are different than the commercial ones. In public organizations one abstains from bureaucratic institution model, by using mechanisms proven in commercial organizations. The mechanisms, specified and described in the theory of organizations and management, at the same time became an object of interest for the administration.

One of the most important orientations in management of modern organizations, being at the same time one of the approaches that can be used in this case, is the process approach. By putting the economic processes in the center of interest of the management and employees, this approach complements the static approach towards organizations with a dynamic approach, thus fostering the increase of flexibility and susceptibility to change of the whole organization (Odlanicka, 2016).

The objective of this article is to review the concepts concerning the essence of process approach with regard to public organizations. The scope of the overview includes initial identification of the possibilities to use this approach in common courts. 


\section{The concept of public organization}

Public organizations, also named public institutions, are organizations acting in the sphere of public affairs. These activities are regulated by legal provisions. Under the Polish law, public organizations are equated with public entities as entities that carry out public tasks. In view of article 2, item 1 of the Act on the computerisation of entities performing public tasks dated February 17, 2005, these are, among others, government administration bodies, state control and law protection bodies, courts, organizational units of the prosecutor's office, as well as local government units and their bodies, budgetary units, local government budgetary establishments, special purpose funds, Independent Public Health Care Facilities, Social Insurance Institution, Farmers' Social Security Funds, National Health Fund, state or local government legal persons (Journal of Laws 2005, no. 64, item 565). In view of the management sciences, public organizations are defined in literature as entities of the public sector, that cover state and local government institutions and their organizational units implementing public tasks (Kożuch, 2007, p. 127). The objectives of public organization make them stand out in their environment due to their nature, as they ensure the proper functioning of the state, security, environmental protection, health, the state economy control, implementation of public tasks by way of meeting collective needs of local communities (Wytrążek, 2011, p. 325). Moreover, they usually implement several goals at the same time, therefore, their structure is complex.

The basis of management in public institutions is the management theory (Kettl, 2000; Pollitt, Bouckaert, 2000; Fredericson, Johnston, 1999; Donahue, Nye, 2002), the public choice theory that covers with its scope the problems of decision-making, especially concerning costs and the manner of goods management (Frąckiewicz-Wronka, 2010). What is also important is the nature and the manner of public goods allocation and the presence of external factors in the economy (Siwińska, 2005), as well as the needs to carry out research over the organization and the functioning of public sphere, especially in the scope of relations towards its role and importance when it comes to meeting the social needs and the possibility of effective functioning (Frąckiewicz-Wronka, 2010).

With regard to public organizations, general management rules are used. Since, however, the context in which they are to be used changes, reference to public organizations requires taking into account their specific nature. The public organization management is based on management logic in private sector (Drucker, 1990; Hughes, 2003), nevertheless, attention is paid to the specific nature of this area. In the literature it is indicated that it is based on the following:

- The fact that profit is not the basic measure of efficiency.

- Assessment made from the point of view of citizens' preferences, legislative choices, as well as political interests.

- Orientation of the participants to the implementation of the mission of the organization. 
- The necessity to go outside of the organizational borders to properly analyze the aspects of problem solving.

- The assumed and expected transparency in action.

- Co-existence of multiple stakeholders, whose interests may be contradictory.

- The influence of the groups of stakeholders the representatives of which hold power.

- Implementing tasks in an environment shaped by the current politics (Lynn et al. 1999; Rainey, 2003; D’Aunno, 2006).

Important are such features as: openness, responsibility, transparency, focus on the results and effectiveness (Odlanicka-Poczobutt, Horodecka, 2018).

Currently, management in public organizations, integration and coordination processes are inseparably linked with process approach and only in such a layout they can be analyzed. A consequence, on the organizational level, is the formation of organizational forms of linked entities that implement public tasks for the purpose of public management (Christensen, 2012; Iacovino et al. 2017).

\section{The essence of process approach}

In economic practice, process approach is compared with the issue of improvement of effectiveness and efficiency of functioning of the organizations, the objective of which is to create and offer the highest possible value for their customers. In this approach, the most important element is the process.

The most frequently cited definitions define the process as:

- a specific and logical sequence of activities in time and in space that are ordered and codependent, with well-defined data and results and well-defined input and output, as well as organized, measurable set of activities that aim to create a specific output being the final element for a specific customer (Davenport, 1993; Hammer, Champy, 1996; Rummler, Branche, 2000; Brilman, 2002; Skrzypek, 2002; Walas-Trębacz, 2013);

- a group of interlinked activities that form a whole, where the input element is transformed into output element (Perechuda, 2000; ISO 9001:2008; Maciejczak, 2011), creating value from the customer's point of view (Hammer, Champy, 1993);

- a sequence of interlinked and codependent activities resulting in specific changes and having as an aim the achievement of a specific final result (Lichtarski 2004), that is creation of value for the customer (Skrzypek, Hofman, 2010; Maciejczak, 2011).

Processes management and process management should be treated as identical terms (Bijańska, Wodarski, 2018). 
The essence of processes management is defined by:

- division into stages (Table 1),

- dimensionality that determines the effectiveness and efficiency of implementation and the use of process management (Czekaj, 2009; Bitkowska, 2013),

- implementation of management function (Skrzypek, Hofman, 2010; Maciejczyk, 2011),

- integration with other concepts, methods and tools that support implementation and the use of process management (Skrzypek, Hofman, 2010; Maciejczyk, 2011; Nowosielski, 2009; Bitkowska, 2013).

Table 1.

Division into stages of process management with indication of the author of the definition

\begin{tabular}{|c|c|}
\hline \multicolumn{2}{|r|}{ Stages of processes management listed in literature } \\
\hline Author/authors & Management stages \\
\hline Grudowski P. & Designing, implementation, supervision and improvement of processes \\
\hline Nowosielski S. & $\begin{array}{l}\text { Identification, modeling and implementation of processes and processes } \\
\text { supervision/assessment of their functioning }\end{array}$ \\
\hline $\begin{array}{l}\text { Skrzypek E., } \\
\text { Hofman M. }\end{array}$ & $\begin{array}{l}\text { Identifying processes objectives, identification and description of processes and measuring } \\
\text { their results }\end{array}$ \\
\hline Bitkowska A. & Identification, modeling, implementation, controlling and improvement of processes \\
\hline
\end{tabular}
Note. Based on Grudowski (2007), Nowosielski (2008), Skrzypek, Hofman (2010), Bitkowska (2013).

Moreover, one should bear in mind that customer focus is typical for process approach.

The use of process approach in public organizations is deemed to improve the tasks implementation (Wiatrak, 2006). Among the elements that distinguish the public organizations management, the following can be listed (Borgonovi, 2018):

- Taking into account public value in the designing of tasks of public organizations.

- Engagement of the society in the results assessment

- Private and public links.

Many linked entities that implement public tasks are engaged in creation of public value understood as the sum of individual benefits provided to the recipients and the outlays needed to source them (Kauf, 2015, p. 122-131). This value is to be understood as something that the society will want, that it will want to achieve, what is valuable for it and what, since the moment it is defined, directs the actions of the society (Koźmiński, Jemielniak, 2008).

Introduction of process approach to the public management makes it possible to use strategic customer focus and, together with it, its key area that is the quality of the rendered services (Krukowski, 2011, p. 24). Such a focus, visible in the processes measurement, is reflected in the quality, flexibility and the time for implementation of the tasks, therefore, in aspects that are particularly important for the organization and for the customers (Grajewski, 2007, p. 79-80).

The division into sequences and ordering activities over time to achieve a specific goal are the common ground for the listed interpretations. Also the Dictionary of the Polish Language defines process as "a course of successive casually connected defined changes being subsequent stages, phases of development of something; course, development, transformation of 
something" (Szymczak, 1978). An aspect that defines the used process approach is the attention paid to the fact that the processes implemented in organizations could be, and even should be, viewed as separate wholes of organic features that can be observed, distinguished and shaped no matter the industry in which they function (Adair, Murray, 2002, p. 22).

\section{The possibilities to use the process approach in courts}

The study on the use of process approach in public organizations of various types are being intensively carried out, which can be proved by the number of literature pieces listed above. In the scope of analysis of common courts as a specific type of public organization there are not many studies especially due to the problem of specific classification of these organizations.

Common courts are the bodies of the judicial authority. They issue judgments on behalf of the Republic of Poland. Due to their nature, they are considered a public organization. The common courts are organized in a three-tier system and in line with article 176, item 1 of the Constitution, the court proceedings shall have at least two stages. The Constitution itself does not define the structure of common courts, but the Law on the system of common courts dated July 27, 2001, in article 1 para. 1 indicates regional, district and appeal courts. Establishment and dissolution of courts, in accordance with article 20 of the said Law lies with the Minister of Justice after obtaining an opinion of the National Council of the Judiciary of Poland.

Moreover, the article 177 of the Constitution provides a rule that the common courts shall implement the administration of justice, which can be limited only on the basis of statutory provisions. It means that common courts are courts of general properties and they administer justice in all cases, except for those reserved by way of law for the jurisdiction of other courts. The common courts, as well as Tribunals, implement their tasks on behalf of the state, which function they are implementing. Therefore, respecting and enforcing the judgments and decisions of the courts is guaranteed by the state, as in line with the article 174 of the Constitution: "the courts and tribunals shall pronounce judgments in the name of the Republic of Poland."

The provisions of the Constitution of the Republic of Poland (article 45, point 1) provide that everyone shall have the right to a fair and public hearing of their case, without undue delay, before a competent, impartial and independent court. The system of common courts organization functioning in Poland is quite complex, as it is characterized by multiple-tier structure and multi-instance court proceedings.

There is no doubt that courts have many stakeholders and in this scope the area of their influence on the community as a public organization is very wide. Figure 1 presents the general map of stakeholders of common courts. 


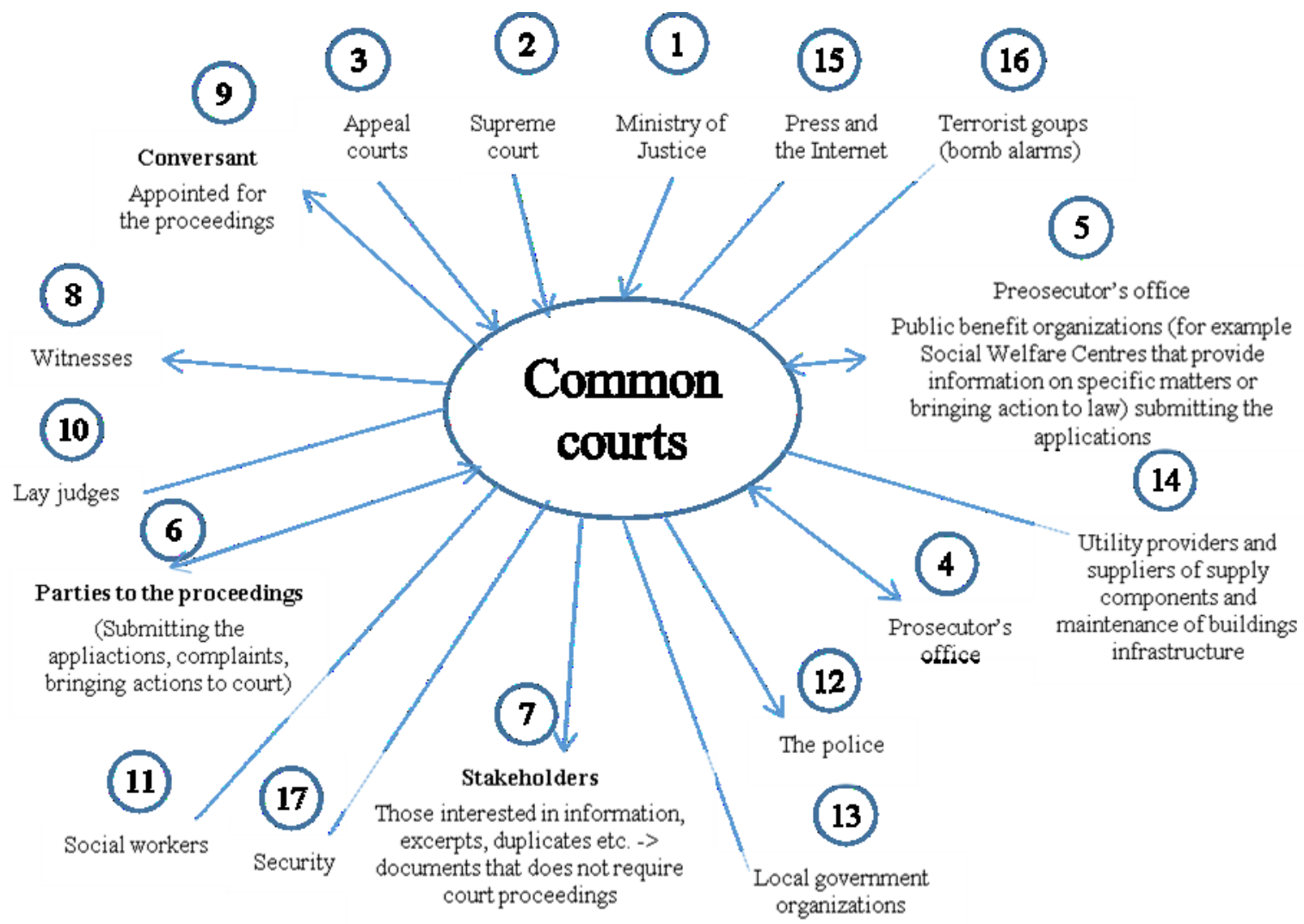

Figure 1. Map of stakeholders of common courts. Adapted from: Odlanicka, 2016, p. 78.

The direct participants of court proceedings are interested in their fast conclusion but the similarity between court proceedings and discreet processes present in production enterprises makes their modeling a difficult task (Odlanicka-Poczobutt, Horodecka, 2018). An additional element is the possibility of branching in the process, due to the importance of making key decisions by the professional staff, meaning judges, where the basis for these decisions are individualized criteria (Flanders, 1980) and multiple aspects.

An important element in processes management in such an organization is also the identification of activities creating value for the citizen and efforts to achieve it when implementing the tasks.

The process orientation in public organizations should mean effective planning, steering and control (Odlanicka-Poczobutt, Horodecka, 2018; Kauf, 2015; Becker, Kahn, 2008). Especially in the aspect of customer focus, when the public benefits are offered as a response to social needs, it needs to be stated that we are dealing with positive effects of the processes being implemented, that will always be linked with the resources used to influence the community and with the rendered services (Kauf, 2015).

The definitions of the term "process" usually do not define the nature of the organization that renders these processes, but they can indicate the essence of the value created form the customer's point of view (Davenport, 1993; Hammer, Champy, 1993; Lichtarski, 2004; Skrzypek, Hoffman, 2010; Bitkowska, 2013). Depending on the type of public organization, the implementation of process approach shall require the identification of main and supporting processes and the management. 
The main processes are the ones within which the basic benefits resulting from the type of the organization, usually implemented on the basis of the provisions of law, are being offered. The supporting processes are about ensuring relevant implementation of basic processes (Bitkowska, and Koltenman, 2011, p. 67). In courts, meaning in organizations the main objective of which is not to make profit or limit the costs, and where the rules of functioning are based mainly on the provisions of the basic law (Odlanicka-Poczobutt, 2016, p. 39), distinguishing these two types of processes seems easy. The problem lies, however, in pointing to the elements of management process that are linked with the use of resources, rendered services and influence on the recipients meaning the society. The general model of processes architecture in courts is presented in Figure 2.

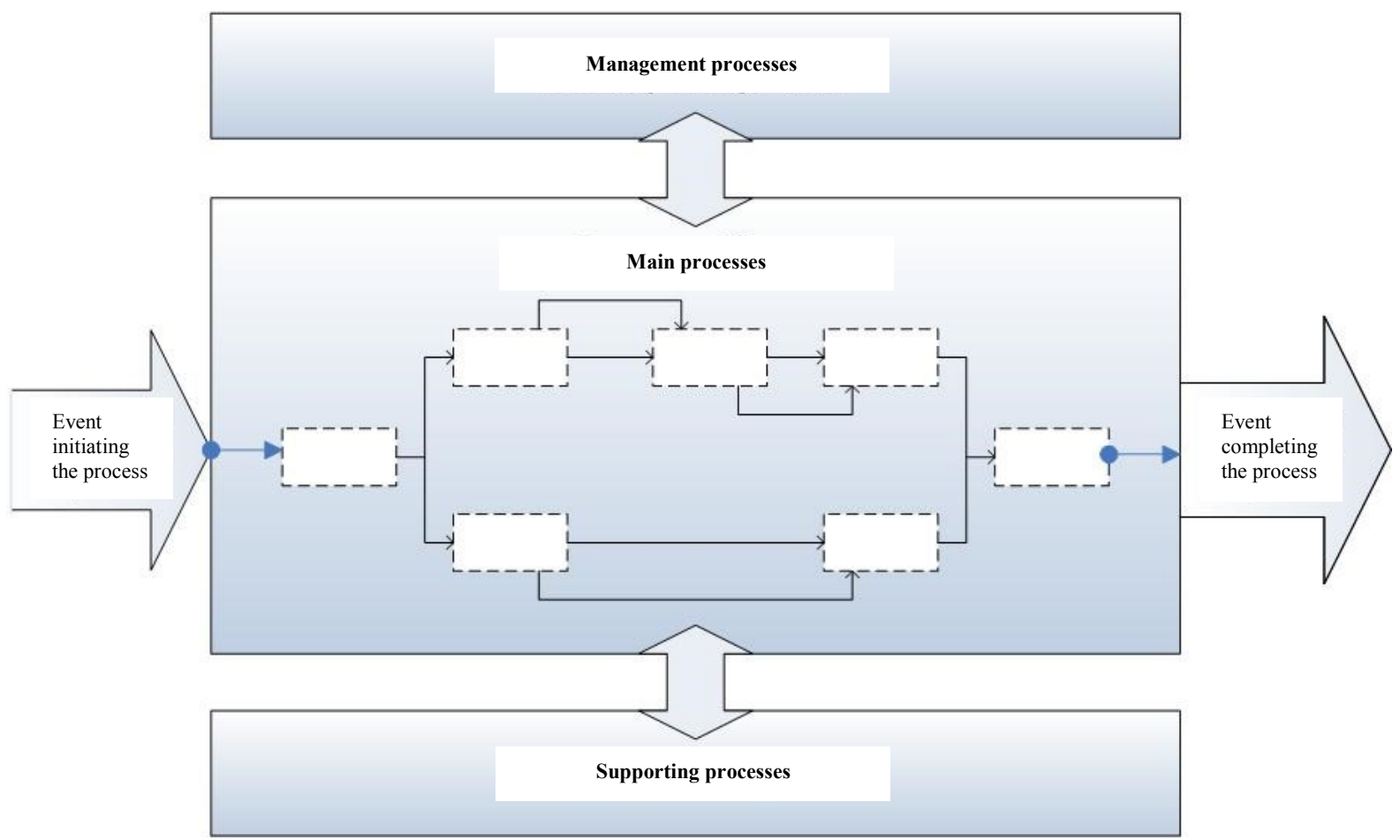

Figure 2. The general model of processes architecture in courts. Adapted from: Odlanicka, 2016, p. 190.

In common courts, to capture these elements one would have to present every process in great detail taking into account daily operations and individual decisions of judges and the expected time of court proceedings completion. Only such an approach to undertaken activities would allow to capture all stages of the process and their transformation into final results. Since the positive effects of the used process approach take place when the offered public benefits respond to the defined social needs, it is necessary to properly plan the processes to create value and to engage relevant resources depending on the type of public organization. 
In common courts, the most important premises for implementation of the process approach are:

1. The nature of the profession that by way of creating value and implementation of statutory obligation boosts the quality of the performed tasks.

2. The repetitiveness of processes based on action patterns, such as substantive procedures requiring specific order of the implemented tasks, strictly defined dates etc.

3. Implementing tasks of various characters and difficulties level, of various level of individualization and complexity require supervision and the control of their course (Odlanicka, 2016, p. 65).

The specific characteristics of courts and the attributes of process approach are presented in Table 2.

Table 2.

Relations between the nature of common courts and the process approach

\begin{tabular}{|c|c|c|}
\hline Specific characteristics of courts & \multicolumn{1}{|c|}{ Attributes of process approach } \\
\hline Statutory obligation & $>$ Creating value \\
& $>$ Automation of tasks \\
\hline & $>$ Reduction of time and costs of processes course \\
Repetitiveness of specific processes & $>$ Standardization and integration of activities \\
\hline Significant level of individualization and & $>$ Assignment of tasks \\
complexity of tasks & $>$ Interactive communication \\
\hline
\end{tabular}

Note. Odlanicka, 2016, p. 194.

The indicated attributes of process approach could become the main stimulator of the development of processes focus in common courts, mostly thanks to the change of functioning on the level of shaping the structure of creating and transformation of value, striving for a wider and more effective use of modern methods and tools in the area of management processes.

When creating conditions to implement the process approach, one should take into account the necessity to eliminate the disruptions resulting in delays the source of which must be searched for in the supporting processes. What would be important is the definition of the scope of these processes implemented in courts and the separation of routine tasks and tasks that are performed rarely, using for example the Glenday Sieve (Fig. 3). 


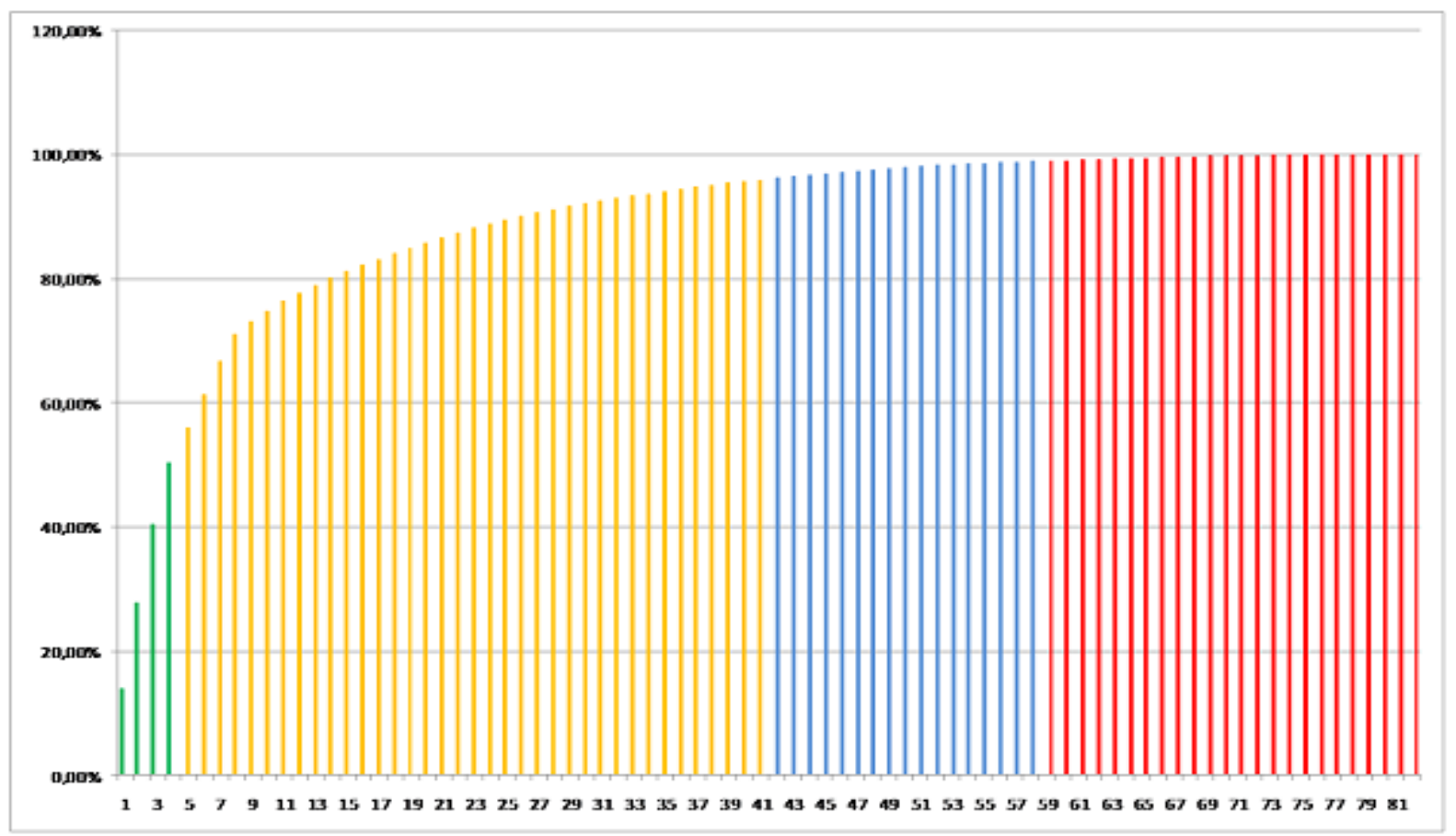

Figure 3. An example of the administrative process analysis with the use of Glenday Sieve. Adapted from: http://lean.org.pl/lean-office-i-lean-administration/.

The example presents the graph of all kinds of tasks preformed in one of the administrative areas, indicating important similarity to the supporting processes taking place in courts, defined as office processes. It can be noticed that only a small part of all tasks ( $6 \%$ of the most frequently performed ones) will be responsible for the implementation of $50 \%$ of all implemented tasks, while $30 \%$ of the most rarely performed ones will be influencing the implementation of $1 \%$ of all activities in a given area (cf. Glanday, 2014, p. 16).

\section{Summary}

Processes implemented in public organizations due to their nature, multidimensional structure and characteristics of the offered benefits are subject to conditions that differ from the conditions in enterprises. When it comes to traditional definition of process approach, one should mention all elements that foster the creation of public value. Depending on the type of public organization, the implementation of process approach shall require the identification of processes being implemented.

When it comes to courts - long time of waiting for the results of the court proceedings and the identified lengthiness when it comes to tasks realizations, which results in the increase of dissatisfaction of the society point to the necessity to look for manners to improve courts functioning. The emerging tendency towards changes, favorable conditions and the necessity to adjust the structure to EU law are the basics to strengthen the need for searching of solutions in other previously unexplored areas. 
In organizations the main objectives of which is not the profit, the identification of main process within which basic benefits are being offered on the basis of provisions of law and supporting (office) processes, is not a difficult task. Indicating elements of management processes that are linked with the use of resources and search for solutions directed towards tasks improvement causes more difficulties. Re-designing processes in many public organizations, also in courts, could result in positive effects, one should start, however, with the analysis of these processes. The implementation of process approach requires also the cooperation between these entities when implementing the tasks.

The implementation of process approach in public sector is an attempt to improve the solutions and to adjust them to the changes taking place in the surroundings. The processes control should be linked with the proper implementation of public benefits and should refer to them, and not be only about the assessment of the level of processes implementation. A key aspect of the use of process approach is the implementation of supraorganizational process thinking and the improvement of management processes.

The considerations were about general overview of the concepts concerning the essence of process approach with regard to public organizations. The initial determination of the possibilities of using this approach in courts shall be the basis for further studies.

\section{References}

1. Act of February 17, 2005 on the computerisation of entities performing public tasks. Journal of Laws of 2005, No. 64, item 565.

2. Act of July 27, $2001 \mathrm{r}$. the Law on the system of common courts, Journal of Laws of 2001, No. 98, item 1070.

3. Adair, C.B., Murray, B.A. (2002) Radykalna reorganizacja firmy. Warszawa: PWN.

4. Becker, J., Kahn, D. (2008). Der Prozess im Fokus. In: J. Becker, M. Kugeler, M. Rosemann (Hrsg.), Prozessmanagement: Ein Leitfaden zur prozessorientierten Organisationsgestaltung. Berlin: Springer.

5. Bijańska, J., Wodarski, K. (2018). Zarządzanie procesami w przedsiębiorstwie górniczym - podstawowe obszary i problem badawcze. Zeszyty Naukowe, Seria: Organizacja i Zarzadzanie, 120.

6. Bitkowska, A. (2013). Zarządzanie procesowe we współczesnych organizacjach. Warszawa: Difin.

7. Bitkowska, A., Koltenman, K. (2011). Zarzadzanie procesami w przedsiebiorstwie. Warszawa: Difin.

8. Borgonovi, E. (2018). Management publico: evoluzione della disciplina e delle riforme. Rivista Italiana di Public Management. Studi e Proposte per Innovare la Pubblica Amministrazione. Roma. Retrived from http://www.RIPM_01_2018_ElioBorgonovi.pdf. 
9. Christensen, T. (2012). Post-NPM and changing public. Meiji Journal of Political Science and Economics, 1.

10. Constitution of the Republic of Poland, Journal of Laws of 1997 no. 78, item 483.

11. D'Aunno, T. (2006). Management scholars and public policy: A bridge too far? Academy of Management Journal, 48.

12. Donahue, J.D., Nye, I.J.S. (2002). Market-Based Governance. Donahue, J.D., Nye, I.J.S. (eds.). Washington: Brookings Institution Press.

13. Drucker, P.F. (1990). Managing the non-profit organization: Principles and practices. New York: Harper Collins.

14. Frąckiewicz-Wronka, A. (2010). Pomiar efektywności organizacji jako obszar korwengencji metod, narzędzi i instrumentów zarządzania między sektorami biznesowym a publicznym. Kwartalnik Naukowy, Organizacja $i$ Zarzadzanie, 4(12). Gliwice: Wydawnictwo Politechniki Śląskiej.

15. Fredericson, G., Johnston, J.M. (1999). Public Management Reform and Innovation. Fredericson, G., Johnston, J.M. (eds.). Alabama: The University of Alabama Press.

16. Glenday, I.F. (2014) Breaking Through to Flow: Banish Firefighting and Produce to Customer Demand. Lean Enterprise Academy Ltd.

17. Glenday, I.F., Sather R. (2014). Lean RFS (repetitive flexible supply): putting the pieces together. CRC Press Taylor \& Francis Group.

18. Grajewski, P. (2007). Organizacja procesowa. Warszawa: PWE.

19. Grudowski, P. (2007). Podejście procesowe w systemach zarządzania jakością w małych i średnich przedsiębiorstwach. In: Podejście procesowe w systemach zarządzania jakościa w MŚP (pp. 194). Gdańsk: Wydawnictwo Politechniki Gdańskiej.

20. Hammer, M., and Champy, J. (1996). Reengineering $w$ przedsiębiorstwie. Warszawa: Neumann Management Institute.

21. Horodecka, A.M. (2018). Podejście procesowe w zarządzaniu publicznym na przykładzie sądownictwa powszechnego - Cz. I. Przegląd historyczny. Zeszyty Naukowe Politechniki Ślaskiej, Seria: Organizacja i Zarządzanie, Konkurencyjność i rozwój regionów $w$ warunkach integracji europejskiej i globalizacji. Stan - Trendy - Strategie, 129.

22. Hughes, O.E. (2003). Public management and administration. An introduction. New York: Palgrave Macmillan.

23. Iacovino, M., Barsanti, S., Cinquini, N. (2017). Public Organizations Betwen Old Public Administration, New Public Management and Public Governance: the Case of the Tuscany Region. Public Organiz Rev, 17, 61-82.

24. Kauf, S. (2015). Orientacja procesowa w zarządzaniu publicznym łańcuchem dostaw. Studia Ekonomiczne. Zeszyty Naukowe Uniwersytetu Ekonomicznego w Katowicach, 251.

25. Kettl, D.F. (2000). The Global Public Management Revolution. A Report on the Transformation of Governance. Washington: Brookings Institution Press. 
26. Kleer, J. (2005). Identyfikacja dóbr wytwarzanych przez sektor publiczny. In: J. Kleer (ed.), Sektor publiczny $w$ Polsce i na świecie. Między upadkiem a rozkwitem (pp. 9-53). Warszawa: CeDeWu Sp.z o.o.

27. Koźmiński, A., Jemielniak, D. (2008). Zarzadzanie od podstaw. Podręcznik akademicki, Warszawa: Wydawnictwa Akademickie i Profesjonalne.

28. Kożuch, B. (2007). Nauka o organizacji. Warszawa: Wydawnictwo CeDeWu.

29. Lynn, I.E., Heinrich, C.J., Hill, C.J. (1999). Studying governance and public management: Challenges and prospects. Chicago: Harris School.

30. Maciejczak, M. (2011). Zarzadzanie procesami biznesowymi w teorii i praktyce. Warszawa: Wydawnictwo PJWSTK.

31. Nowosielski, S. (ed.) (2008). Procesy i projekty logistyczne. Wrocław: Wydawnictwo Uniwersytetu Ekonomicznego.

32. Nowosielski, S. (ed.) (2009). Podejście procesowe $w$ organizacjach. Uniwersytet Ekonomiczny w Krakowie.

33. Odlanicka-Poczobutt, M. (2016). Modele procesów logistycznych w sadownictwie powszechnym. Gliwice: Wydawnictwo Politechniki Śląskiej.

34. Odlanicka-Poczobutt, M., Horodecka, A.M. (2018). Podejście procesowe w zarządzaniu publicznym na przykładzie sądownictwa powszechnego - Cz. II. Wstępne zalecenia. Zeszyty Naukowe Politechniki Śląskiej, Seria: Organizacja i Zarządzanie, Konkurencyjność i rozwój regionów w warunkach integracji europejskiej i globalizacji. Stan - Trendy Strategie, 129.

35. Perechuda, K. (ed.) (2000). Zarządzanie przedsiębiorstwem przyszłości - koncepcje, modele, metody. Warszawa: Placet.

36. Pollitt, Ch., Bouckaert, G. (2000). Public Management Reform. A Comparative Analysis. Oxford: Oxford University Press, 2000.

37. Rainey, H.G. (2003). Understanding and managing public organizations. San Francisco: Jossey-Bass,

38. Siwińska, J. (2005). Ewolucja sfery publicznej w gospodarce. In: J. Wilkin (ed.), Teoria wyboru publicznego. Wstęp do ekonomicznej analizy polityki i funkcjonowania sfery publicznej (pp. 30-41). Warszawa: Wydawnictwo Naukowe Scholar.

39. Skrzypek, E. (2002). Jakość i efektywność. Lublin: Wydawnictwo UMCS.

40. Skrzypek, E., and Hofman, M. (2010). Zarzadzanie procesami w przedsiębiorstwie. Warszawa: Oficyna a Wolters Kluwer Business.

41. Słowiński, B. (2009). Inżynieria zarzadzania procesami logistycznymi. Wydawnictwo Uczelniane Politechniki Koszalińskiej.

42. Szymczak, M. (ed.) (1978). Słownik języka polskiego. Warszawa: PWN, 926.

43. Wytrążek, W. (2011). Podstawowe pojęcia teorii organizacji i zarządzania w instytucjach publicznych. In: P. Kawalec, R. Wodzisz, P. Lipski (eds.), Podstawy naukoznawstwa. Lublin: KUL. 